\title{
Museo de Arte Contemporáneo de Santiago (M.A.S.): Ex-feria Persa Internacional II, Etapa Parque de los Reyes
}

\section{Valentina Garretón L. / Profesor Guía: Óscar Ortega}

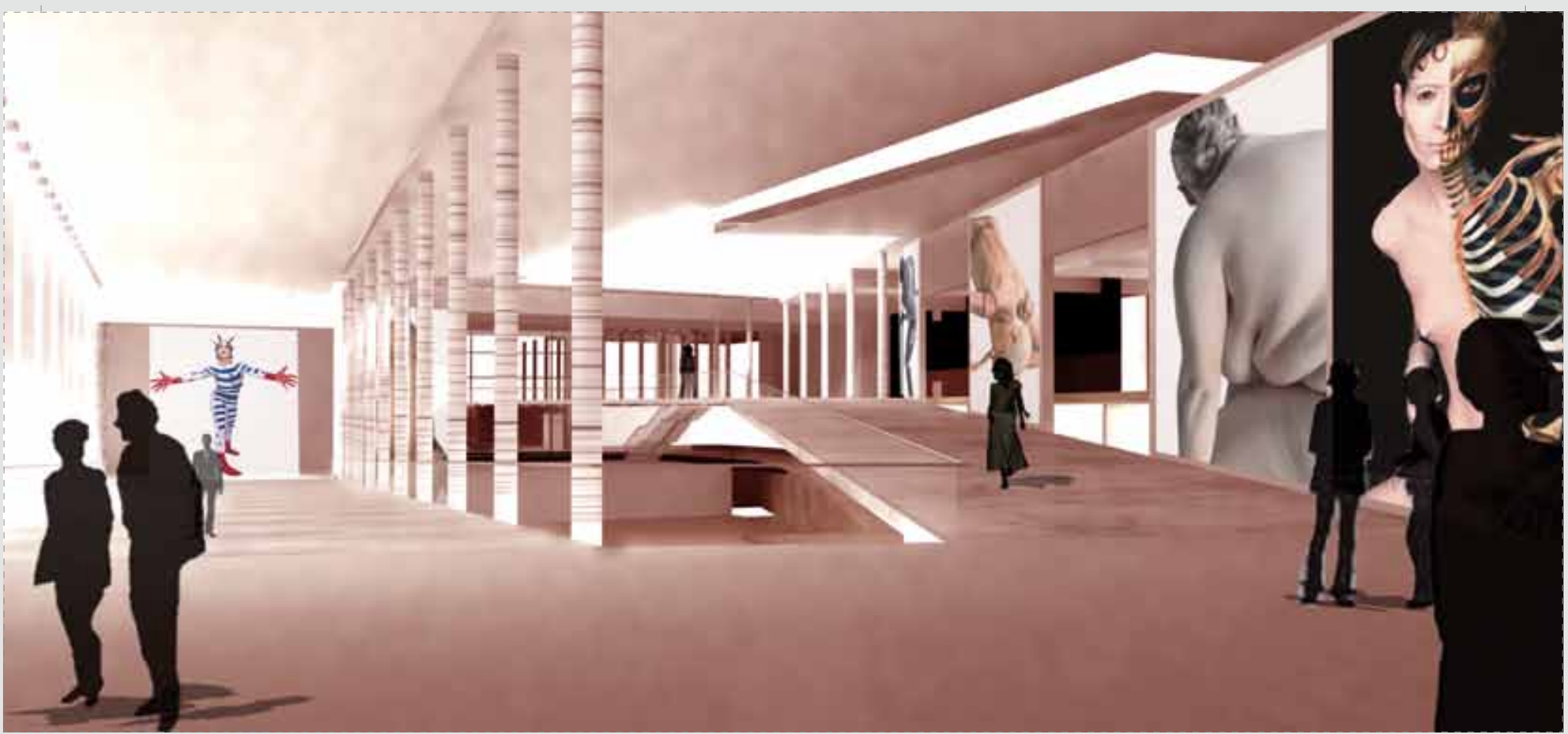

Se propone un nuevo edificio para el Museo de Arte Contemporáneo de Santiago que acoja la «problemática de la nueva museología»: el "cómo» se plantea el tema del museo hoy y su relación, con la colección, con el público y con el contexto en el cual se inserta.

El Museo de Arte Contemporáneo es hoy una instancia urbana de relación, de cultura y espacio público y debe cumplir un rol reactivador de ciudad a través de un camino de descubrimiento al interior de la cultura y el espíritu.
El encuentro con el arte se produce en un espacio de excepción urbana, de margen con respecto a la trama espacial y temporal. El lugar es señal de las estructuras fundadoras de la ciudad, la continuidad de las redes culturales existentes y la recuperación de un territorio en deterioro dentro del «circuito museal de Parque Borde-Río» interrumpido hoy entre el Parque Forestal y la Quinta Normal.
El nuevo museo trabaja con los conceptos de jardín, escenario y puente. Es un edificio mixto que mediante la teoría del movimiento reconoce el sentido longitudinal del parque, traza un recorrido interior simultáneo que actúa como puente subterráneo que a nive de superficie ofrece el vacío que dramatiza la ausencia de identidad. 

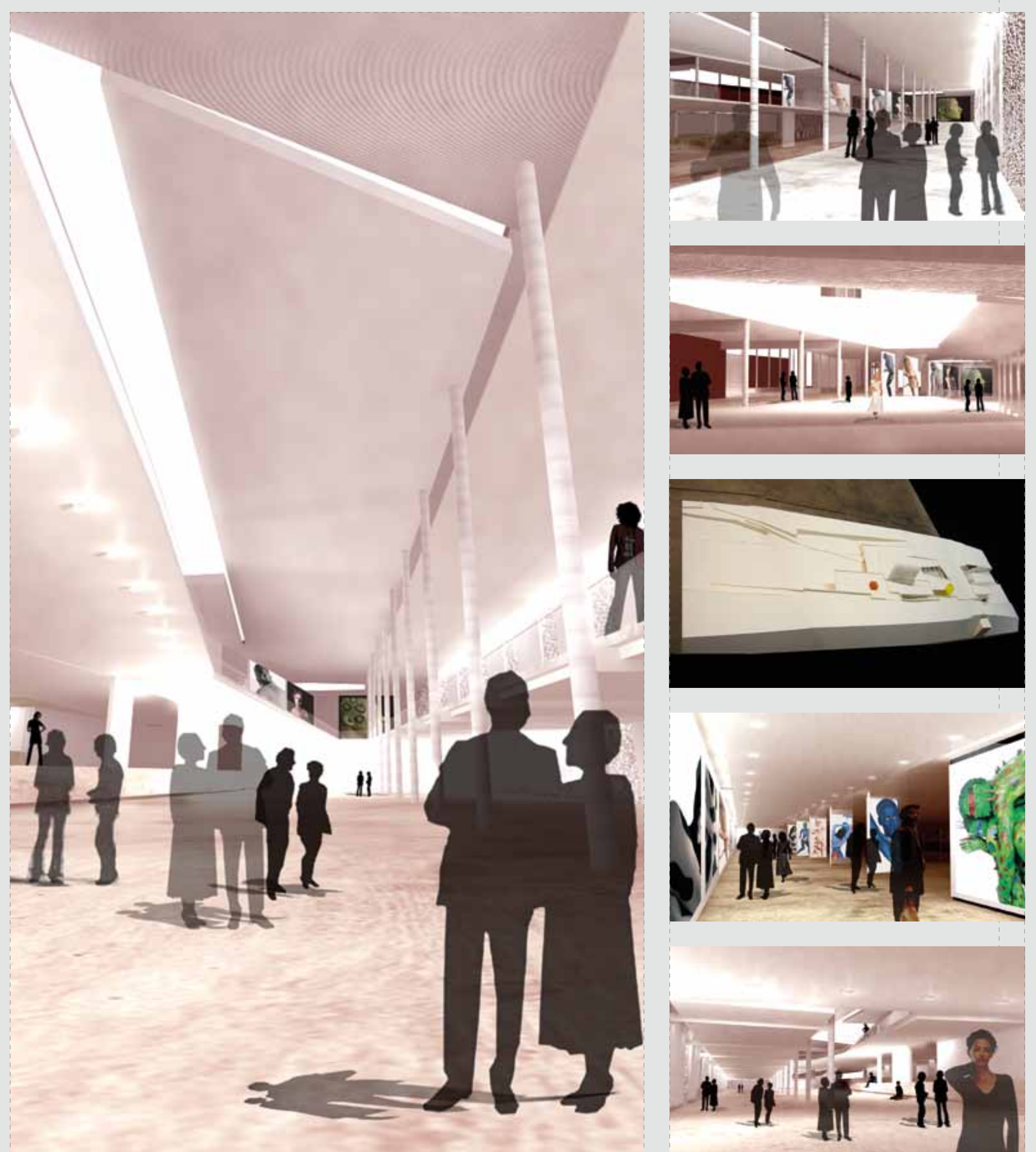